\title{
'For the house her self and one servant': Family and Household in Late Seventeenth-century London
}

\author{
Mark Merry and Philip Baker \\ Centre for Metropolitan History, Institute of Historical Research, London
}

The 1695 returns for the marriage duty tax provide a unique opportunity to investigate the composition of London's domestic groups. Traditional schemes for the analysis of the early modern family and household fail to capture the complexities of metropolitan living, and a 'London-specific' methodology is outlined for use in the returns' classification. Application of this scheme to returns from two contrasting areas of London, a cluster of wealthy city-centre parishes and a poorer suburban precinct, reveals a series of structural differences in their families and households that are attributable to the wealth and social status of their respective populations. However, some aspects of the domestic experience within the two areas are more comparable than previous accounts would suggest.

\section{Introduction}

The final decades of the seventeenth century constitute a vitally important period for those who study the social and demographic characteristics of England's population in the time before the first official modern census. ${ }^{\mathrm{I}}$ As a result of the increasing financial demands on the post-restoration state, both traditional and new forms of national taxation were imposed on the populace, and these generated a wealth of detailed documentation that readily lends itself to historical analysis. The returns from the hearth tax and the 'four shillings in the pound' aid, for example, provide lists of named householders with individual assessments that can be used as indicators of economic status; while the most descriptive sources - the returns from the poll tax and, in particular, the marriage duty assessments — provide a unique insight into the internal composition of the families and households of the period. Peter Laslett and other scholars used these and similar lists of inhabitants in their influential study of the size and structure of the domestic group, Household and Family in Past Time. This work disputed the historical existence of the extended family, and argued that the English pre-industrial domestic group was invariably small and nuclear in its organisation, with a mean household size of fewer than five people. ${ }^{2}$ However, 
subsequent research has highlighted the need to incorporate regional variations into this national picture, with perhaps the most important being the distinctive case of the metropolitan household.

It is now widely recognised that households in early modern London exhibited particular structural forms, characterised by the relatively high incidence of lodgers, apprentices and servants, and the relatively low incidence of children; and Richard Wall has argued that London is 'the only clear candidate for an area with a distinct household structure'. ${ }^{3}$ The mean number of cohabitants within a single house (or 'housefuls', as we shall term them) was also considerably greater in the capital than elsewhere in the country. ${ }^{4}$ Nevertheless, studies of the metropolitan domestic group have arguably relied upon methodological approaches that are better suited to the less complex arrangements found outside of London, where the majority of households conformed to the simple model of the nuclear family, with or without servants, living on its own. For example, the scheme for the classification of lists of inhabitants pioneered by the Cambridge Group for the History of Population and Social Structure makes it difficult to incorporate, and thus to examine, the very characteristics that made London unique, including the frequency of co-resident households and the high numbers of lodgers and inmates. ${ }^{5}$ Similar criticisms might also be levelled at a number of the interpretative decisions that underlay the work of both David Glass and Craig Spence. ${ }^{6}$

This article addresses this anomaly by providing a study of the city's families and households that is based on a newly developed, 'London-specific' methodology, which subdivides the metropolitan domestic group in order to retain and analyse its full complexity. The scheme, which is outlined in the following section, permits a more comprehensive analysis of the size and structure of the metropolitan domestic group and its component parts than has previously been undertaken. The results of the inquiry offer a series of quantitative data that could be used to investigate a number of issues concerning the capital's domestic experience that are often studied through qualitative sources, such as the following: the apparent scarcity of children as a symptom of social breakdown; high numbers of servants and apprentices, and their perceived connection to disorder; a perceived increase in the number of broken marriages; and the harbouring of lodgers, strangers and other potentially unruly individuals. ${ }^{7}$

An important concern here, in terms of the development of London, is whether these trends were characteristic of the metropolis as a whole or whether they were a feature of particular regions of the city with distinct social and economic profiles. Whereas, across London, the medieval intermingling of rich and poor at the level of the parish persisted throughout the seventeenth century, historical models of the social topography of the city — such as the traditional concentric circle pattern, which located the wealthiest inhabitants in the city centre and the poorer population towards the periphery, congregating in the suburbs; or the distinction between the wealthier west end and poorer east end of the metropolis - nevertheless reflect broad reality. ${ }^{8}$ Although scholars have considered the link between the wealth and size of housefuls, there are, however, few detailed studies of the relationship between social and economic status and the internal structure of the family and household in contrasting areas of London. 9 As a result, this article draws on lists of inhabitants 
from one intramural and one extramural study area: the first is a cluster of four small, relatively wealthy, inner-city parishes at the eastern end of Cheapside - All Hallows Honey Lane, St Martin Ironmonger Lane, St Mary Colechurch, and St Mary le Bow; and the second is the suburban precinct of Tower Hill, lying to the east of the city in the large and poor parish of St Botolph Aldgate (Figure I). Existing studies would lead us to expect that the contrasting wealth and social characters of these two populations would result in noticeable differences in the size and structure of both their families and households. ${ }^{\text {I0 }}$ But while the results based on our methodology do illustrate marked contrasts in the composition of their respective households that can indeed be attributed to social and economic factors, they also reveal a perhaps surprising number of shared household characteristics. Moreover, at the level of the family, we find an even more striking series of similarities - and unexpected differences - in the family units within both areas. In this way, the findings of this study contribute to the debates concerning the development of the social landscape of London, the size and composition of the early modern household, and whether the late seventeenth century witnessed a period of crisis for the metropolitan family.

\section{Sources and methodology}

This article provides a detailed analysis of the two study areas' marriage duty assessments, the source that scholars agree provides the most complete coverage of local populations among the various late seventeenth-century taxation returns. That coverage was probably not comprehensive, but the records undoubtedly represent the 'best measure for determining the number of people and households in the city'. ${ }^{\text {II }}$ Marriage duty assessments were the product of a form of taxation on births, marriages and

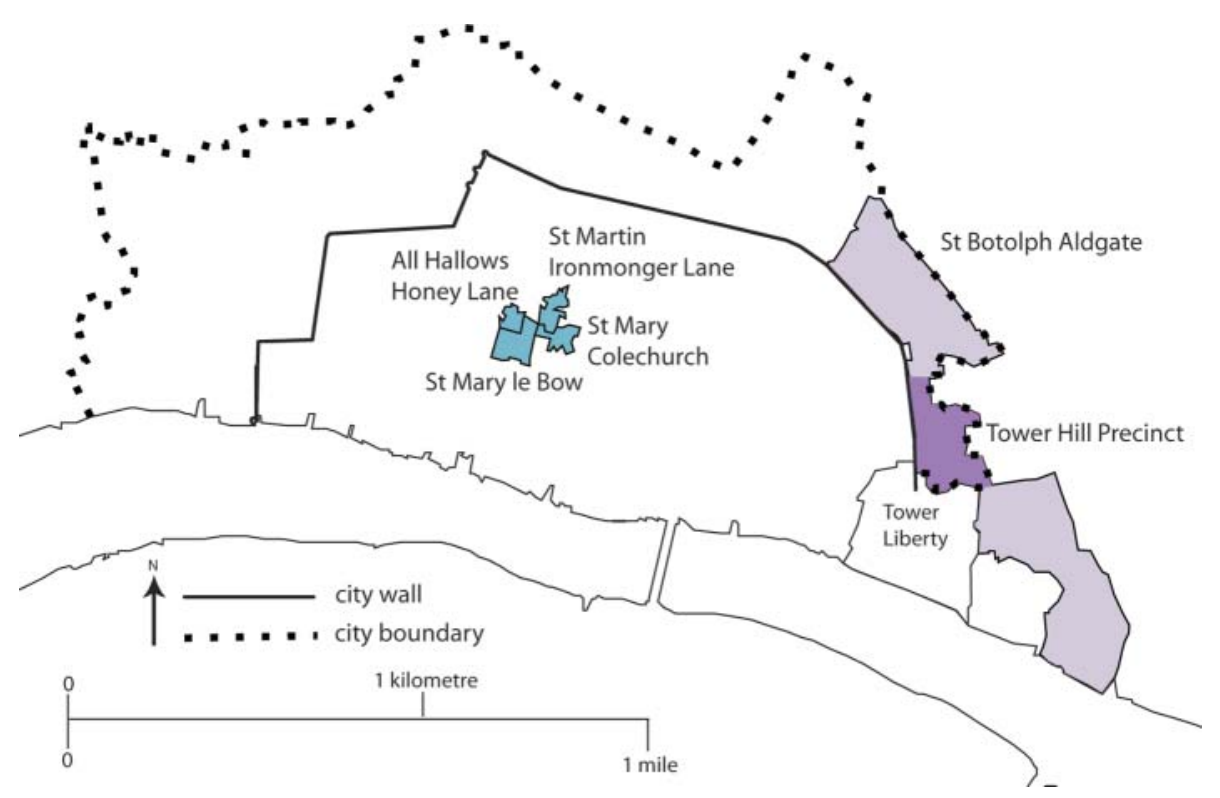

FIGURE 1 The Cheapside and Aldgate study areas. 
burials, and of annual payments by bachelors aged over 25 years and childless widowers. The tax was in force from I695 to I706, and imposed a standard charge for vital events and annual payments, and additionally enforced a graduated system of surcharges based on wealth and social status. ${ }^{\mathrm{I2}}$ By the provisions of the Marriage Duty Act, assessors were to obtain 'the names sirnames estates degrees titles and qualifications of all and every the persons dwelling or residing within the limits' of an area, with servants and lodgers to be taxed where they lived. Lists were therefore compiled of all the inhabitants within a specific locale, indicating the duties for which they were or would become liable (with those in receipt of alms being exempt from the financial provisions of the act). ${ }^{\mathrm{I} 3}$ The result was a series of parish assessments that resemble census-like lists of inhabitants. Unfortunately, the survival of these lists is extremely patchy nationwide, and the only extant assessment returns for London are those for 1695 . There is also some variety in the nature of the assessments, perhaps attributable to the different decisions that individual enumerators made in their compilation. Nevertheless, the vast majority of the returns group people together in distinct blocks of names, taken to indicate all those inhabiting the same house, and often describe the nature of the relationship between individuals. In addition, they frequently provide indicators of personal social and marital status, economic standing and, in some instances, age. ${ }^{\mathrm{I}}$

As noted above, the information in the marriage duty assessments has been classified according to a 'London-specific' methodology that analyses the data at four levels: the houseful; the household; the family; and the unit. At the top level of the scheme, the houseful simply corresponds to each distinct group of inhabitants demarcated by the contemporary compiler of the list, which we are treating as a distinct house (although not necessarily a separate, individual building). ${ }^{15}$ The next two levels use both the given relationships in a list and a consistently applied and specific set of rules and presumptions - which incorporates inhabitants' surnames, explicitly stated relationships, status, and position within a list - to impose divisions that enable consistency in classifying and analysing the internal composition of the houseful. Thus, the second level of the scheme, the household, groups together those inhabitants united by actual or presumed - according to the defined rules — kinship, economic and servitude relationships. The third level, the family, comprises all those individuals stated — or, again, presumed — to be related to each other either by blood or by marriage. ${ }^{\mathrm{I}}{ }^{6}$ Of course, the distinction made here between household and family is anachronistic (to contemporaries, the words may have been synonymous), but by defining precisely what those terms mean within this scheme, we hope to avoid the existing historiographical muddle over their relationship, and to be exact in our own units of analysis.

The fourth and final level of the scheme, the unit, is concerned with explicitly stated relationships in a list. A unit is therefore either an individual with no designated relationship to any other person, or a group of two or more individuals who are explicitly linked by a relationship described in a list. The unit is particularly useful in allowing a degree of flexibility within the overall scheme when confronted by problematic houseful structures, while also maintaining the integrity of the source (by allowing the removal of any 'analytical assumptions' from the data imposed by 
the second and third levels). For example, although the majority of housefuls containing co-resident families with servants list each family and its servants sequentially, some list families one after the other and all of the houseful's servants in a separate group listed at the end. Marking the servants as single units not only preserves the integrity of the original source, but also retains their relationship to the houseful for analytical purposes, as they must be in service to one, or a combination, of the cohabitant families.

The top two levels of the scheme are clearly depicted in Figure 2. The section of the St Mary Colechurch marriage duty assessment shaded in grey is the actual transcript of the manuscript (omitting the sums that individuals were assessed at), and the thick black horizontal lines represent explicit demarcation between blocks of names - what we identify as housefuls. The dotted lines denote our identification of households according to the rules of the scheme. Thus, James Lombard, William Chandler, Lydia Price, Thomas Lawrence, Benjamin Bolton and Henry Ashton are all heads of their own households: the first three households co-reside in the twelfth house visited by the compiler of the assessment, while the latter three occupy the thirteenth listed house. A comparison with the names in a St Mary Colechurch poor rate listing of 1695 suggests that the individuals italicised in Figure 2 were indeed treated as householders in their own right (although Lydia Price is missing from the poor rate; in the first quarterly poll tax of 1694 she is described as a lodger, along with John Price and William Chandler, also listed as lodgers, in the house of James

Marriage Duty Assessment 1695

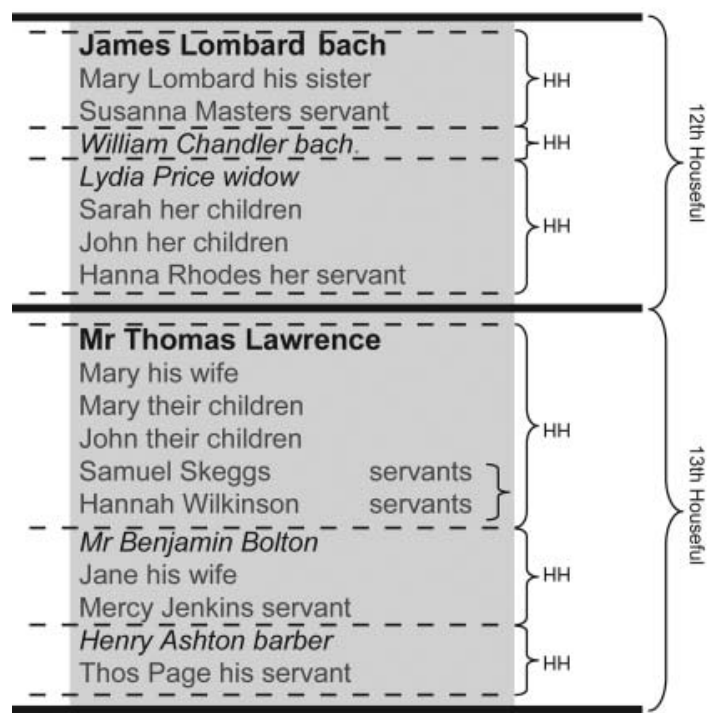

Poor rate 1695

\author{
John Hayes 19s 6d \\ James Lombard 19s 6d \\ William Chandler $6 s$ $6 d$ \\ Thomas Lawrence 19s 6d \\ Benjamin Bolton or successor $6 s$ d \\ Henry Ashton or successor $6 s$ 6d \\ William Reynolds 13s
}

FIGURE 2 An extract from the marriage duty assessment for St Mary Colechurch, showing level 1 (houseful) and level 2 [household $(\mathrm{HH})$ ] classifications, with a contemporary poor rate listing for comparative purposes. Source: London Metropolitan Archives (LMA), COL/CHD/ LA/04/01/063, f. 4; Guildhall Library Manuscripts Section (GLMS), 66, f. 259. 
Lumbard $^{17}$ ), as indicated by their qualification to contribute to the rate. That is, it was not simply James Lombard and Thomas Lawrence, the first-named individuals in each block of names, who were seen as householders. This is not to say that the italicised householders were necessarily occupying these houses on equal terms with the Lombard and Lawrence households (they may have been subtenants, for example, as they were not described as lodgers in the more accurate marriage duty assessment), and, indeed, the amount that these householders were assessed for in the poor rate may be suggestive of their relative status. However, it does provide evidence that has led us to reject the Cambridge Group's rule of identifying each demarcated block of names as a single discrete household. ${ }^{\mathrm{I}}{ }^{2}$

In this and other ways, the application of the four-level scheme to the marriage duty assessments generates a number of extremely useful methodological benefits. It enables an examination of the domestic groups inhabiting the two sample areas at multiple levels. Moreover, it can take into account the different groups to which an individual belonged by virtue of the particular physical, social and economic environments of London. Distinctions based on biological and legal characteristics have a tendency, of course, to fragment domestic units in ways that contemporaries might not have done. However, such distinctions are inevitable in this field of historical enquiry, and the four-level scheme provides a methodology through which to analyse the assessments in a consistent way. Finally, it also provides a clear and precise terminology in an area of scholarship in which words and their definitions are of crucial importance. ${ }^{\text {I9 }}$

\section{The Cheapside and Aldgate study areas}

The relationship between social and economic status and household and family forms is surprisingly understudied in the existing literature; this article investigates the character of the domestic group in two distinct areas of the metropolis with contrasting tax and rental values. In Spence's mapping of London's wealth in the I690s, the Cheapside sample area falls into his highest category of land value $\left(£_{2}, 028\right.$ to $£_{5}, 699$ annual rack-rent per hectare), while Aldgate falls into the significantly lower land value category of $£_{797}$ to $£_{I}, 489$. Similarly, the east end of Cheapside falls into one of Keene's focal points of wealth and land value, while Aldgate is on the periphery. ${ }^{20}$ In terms of population density, the two study areas are similarly distinct, with the Cheapside parishes being somewhat more densely settled than Aldgate. ${ }^{2 I}$

Located in the historic commercial heart of the city - and thus representative of the centre of the concentric circle pattern of the social topography of London the Cheapside study area of four small parishes covering approximately seven acres housed about I,500 people in I695. In the same year, the Io-acre precinct of Tower Hill was home to just over 2,000 of the inhabitants of the parish of St Botolph Aldgate (Table I). Lying on the periphery of the city in its eastern suburbs, St Botolph was a large and relatively poor parish, but it was also an area that had undergone a recent and spectacular period of population increase, building expansion and industrial development; and it has been argued that this suburban district was more representative of the social and economic environment experienced by the majority of Londoners by the late seventeenth century. ${ }^{22}$ 
TABLE 1

NUMBER OF DOMESTIC GROUPS IN CHEAPSIDE AND ALDGATE, 1695

\begin{tabular}{lccccc}
\hline Area & $\begin{array}{c}\text { Total } \\
\text { population }\end{array}$ & $\begin{array}{c}\text { Total } \\
\text { housefuls }\end{array}$ & $\begin{array}{c}\text { Total } \\
\text { households }\end{array}$ & $\begin{array}{c}\text { Total } \\
\text { families }\end{array}$ & Total units \\
\hline All Hallows Honey Lane & 194 & 26 & 54 & 55 & 125 \\
St Martin Ironmonger Lane & 254 & 40 & 82 & 82 & 213 \\
St Mary Colechurch & 358 & 54 & 108 & 111 & 183 \\
St Mary le Bow & 672 & 105 & 185 & 188 & 429 \\
Cheapside sample & 1,478 & 225 & 429 & 436 & 950 \\
Tower Hill precinct (St Botolph Aldgate) & 2,082 & 465 & 808 & 808 & 1,607 \\
\hline
\end{tabular}

SOURCE: LMA, COL/CHD/LA/04/01/004, 053, 062, 063, 102.

Within both study areas, there were densely packed units of housing, with multiple and separate households cohabiting and sharing entrances, stairwells, yards, and cooking and washing amenities. By the later Middle Ages, the basic form of London's housing stock, particularly those houses with frontages on the principal streets, had been established, and this would remain largely unaltered until the eighteenth century, despite developments in building techniques and the availability and adoption of new building materials. Terraces of four- or five-storey houses, often built over stone cellars and surmounted by a garret, were the most common form of housing along streets, particularly in the city's wealthier districts, such as our Cheapside sample area. Sitting on plots four metres to six metres wide, these could be easily employed for commercial uses by London's artisans and retailers, as well more simply as spacious domestic premises by wealthy occupiers. The plans of these houses followed a common pattern, but the allocation of rooms on upper storeys, and towards the rear of the plot, or located in outhouses, could be complex and varied, leading to divisions and subtenancies held from different landlords. Houses at the rear of plots, and within alleys and courts, were usually smaller and had one or two fewer storeys.

The population expansion of the seventeenth century led to rapid and localised ad hoc building programmes in the capital's marginal districts, resulting in poor-quality housing in areas hitherto known for the availability of recreational activities - such as St Botolph Aldgate. These uncoordinated building booms also led to a sharp distinction in the nature of building use between the city and the suburbs. ${ }^{23}$ In poorer, more industrial areas such as Aldgate, houses tended to be lower-quality, smaller buildings with fewer storeys than those in central city areas (although single-storey houses were rare even here), with plans designed around a single room per storey. The reasons for this lay partly in the fact that new building was centred in areas around the evolving alleys and courts that sprang up between main thoroughfares, meaning that the space to build into was delineated by existing rows of housing; and partly in the nature of the population that came into the area looking for accommodation (who were predominantly young, poor and single). In both Cheapside and Aldgate, more substantial houses were juxtaposed (often in close proximity) to poorer houses, although the preponderance of each reflected the areas' respective 
economic and social characters: as a rule, houses in Cheapside were larger, better maintained and more comfortably appointed and lavishly furnished than those in Aldgate, even after the post-Fire rebuilding. ${ }^{24}$ Nevertheless, in both areas, housing was highly sought after, and competition for living space was considerable. ${ }^{25}$

The households occupying these houses were clearly influenced by the physical environments that they occupied, their character and composition being shaped by the housing stock, its size, quality, value and availability. In Cheapside, housing was more spacious, whereas in Aldgate, the spate of property development that took place in the mid-seventeenth century, when the division of houses and building over interconnecting spaces became established practices, contributed to the pattern of smaller dwellings in that suburb. The complex and constantly changing pattern of alleys and yards in Tower Hill precinct in the ensuing period, which is evident in the maps of the city from the last decades of the seventeenth century, was a consequence of this reconfiguring of living spaces. Moreover, the division of housing was something that concerned the authorities, who associated the social evils and moral decline attendant upon poverty with the living conditions of the area. ${ }^{26}$ Living in these divided spaces, combined with the social and economic pressures that were the cause and effect of doing so, was seen to have led to both the compression and fragmentation of the putative nuclear domestic group described by Laslett and others.

Table 2 reveals that the domestic groups in both sample areas are relatively small, and the difference in the quality of housing stock available to the suburban Tower Hill population, and the extent to which the subdivision of housing had generated smaller property units, is clearly reflected in the precinct's significantly lower mean houseful size in comparison with that for Cheapside. ${ }^{27}$ In fact, the mean number of people living in a single house in Tower Hill accords more closely with the figure of 4.7 , the mean of the 9I provincial parishes studied by Laslett. ${ }^{28}$ There seem to have been two extra people per house living in the Cheapside parishes in comparison with the provincial figure, and these are clearly accounted for by co-resident non-nuclear family members, lodging individuals, and increased numbers of servants and apprentices. In the Cheapside parishes, households were slightly larger than their counterparts in Tower Hill precinct, although, interestingly, families were the same mean size. As we will discuss in detail below, this difference is indicative of the relative economic and social characteristics of the two areas.

TABLE 2

MEAN HOUSEFUL, HOUSEHOLD AND FAMILY SIZES IN CHEAPSIDE AND ALDGATE, 1695

\begin{tabular}{lccc}
\hline Area & $\begin{array}{c}\text { Mean houseful size (mean number } \\
\text { of cohabitants within a single house) }\end{array}$ & Mean household size & Mean family size \\
\hline Cheapside sample & 6.6 & 3.4 & 2.3 \\
Tower Hill precinct (Aldgate) & 4.5 & 2.5 & 2.3 \\
Laslett's London sample & 5.75 & - & - \\
\hline
\end{tabular}

SOURCE: LMA, COL/CHD/LA/04/01/004, 053, 062, 063, 102; P. Laslett, 'Mean Household Size in England Since the Sixteenth Century', in P. Laslett with R. Wall (eds), Household and Family in Past Time (Cambridge, 1972), 125-58, Table 4.1. Laslett's London sample is based on the nine London parishes within his 100-parish sample. 


\section{The household}

The household, as Ian Archer has written, was in the 'front line in the maintenance of order throughout early modern English society'. ${ }^{29}$ It was embedded within the community as a unit of social governance, and householders (variously defined as property owners, resident parishioners, the masters of servants, payers of scot and lot) had social and legal responsibilities both within and without the house. Any perceived breakdown of the domestic unit was viewed as a threat to the fabric of society in general. ${ }^{30}$ Households, and the houses that they occupied, could gather a bad reputation, such as that of the widow Russell in Rosemarie Lane, St Botolph Aldgate, who was admonished as a 'Comon harbourer of Strange Ghests to Charge the parish'. ${ }^{3}$ In early modern London, the traditional social role of the household within the community was being undermined by the realities of living within a rapidly burgeoning population and the common practice of sharing houses across the city.

While domestic organisation in rural parishes was often that of one house occupied by one household - centred on a married couple or single parent, children, servants and apprentices - the marriage duty assessments from both of our London study areas indicate that just under half of all houses seem to have been accommodating two or more households in 1695 (Table 3). ${ }^{32}$ In contrast to other studies, the pattern is similar across both areas, although there is a slight shift towards the properties in Cheapside with regards to dwellings housing four or more households. ${ }^{3}$ These latter households tend to be small, often consisting of lodgers, and the larger sizes of properties in Cheapside than in Tower Hill precinct are likely to have made such cohabitation physically possible.

Part of the distinctive character of London's domestic groups arises from the presence of lodgers, and what is evident from the marriage duty assessments is that lodgers could be domestic groups in their own right, rather than simply lone individuals. The proportion of houses accommodating lodging households or families was significant in both the city-centre parishes and the eastern suburb, and there are implications for the use of space in the management of the domestic environment in houses shared in this way. ${ }^{34}$ Table 4 shows that lodging households and families were, on average, slightly smaller than the 'principal' group in the house: in Cheapside,

TABLE 3

THE NUMBER OF DISTINCT HOUSEHOLDS COHABITING IN CHEAPSIDE AND ALDGATE, 1695

\begin{tabular}{lcccc}
\hline & $\begin{array}{c}\text { Mean number } \\
\text { of households } \\
\text { per house }\end{array}$ & $\begin{array}{c}\text { Number of } \\
\text { households } \\
\text { within houses }\end{array}$ & $\begin{array}{c}\text { Number of } \\
\text { houses }\end{array}$ & $\begin{array}{c}\text { Percentage of } \\
\text { all houses }\end{array}$ \\
\hline Cheapside sample & 1.9 & 1 & 123 & 54.7 \\
& & 2 & 58 & 25.8 \\
Tower Hill precinct (Aldgate) & 1.7 & 4 or more & 21 & 9.3 \\
& & 1 & 23 & 10.2 \\
& & 2 & 128 & 53.8 \\
& & 3 & 57 & 27.5 \\
& & 4 or more & 30 & 6.5 \\
\hline
\end{tabular}

SOURCE: LMA, COL/CHD/LA/04/01/004, 053, 062, 063, 102. 


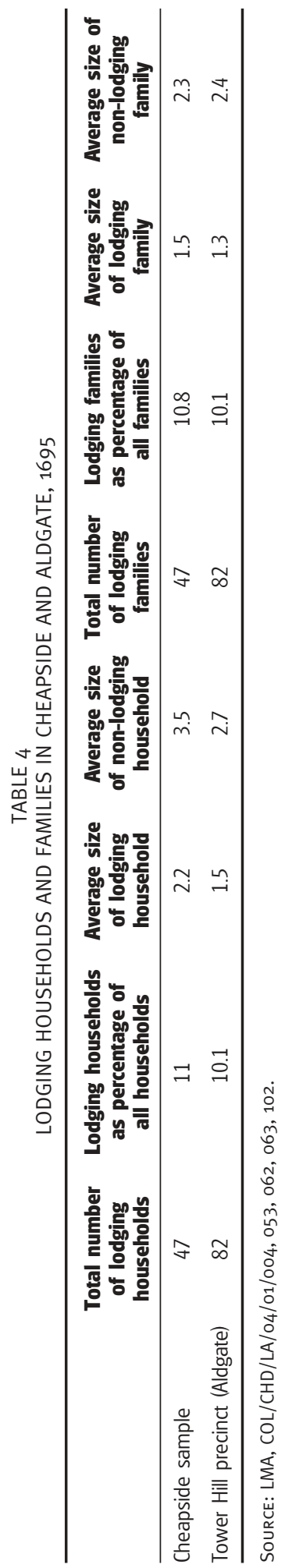


TABLE 5

LODGERS IN CHEAPSIDE AND ALDGATE, 1695

\begin{tabular}{lccccc}
\hline & $\begin{array}{c}\text { Total number } \\
\text { of lodgers }\end{array}$ & $\begin{array}{c}\text { Lodgers as } \\
\text { percentage } \\
\text { of total } \\
\text { population }\end{array}$ & $\begin{array}{c}\text { Number of } \\
\text { houses with } \\
\text { at least } \\
\text { one lodger }\end{array} \begin{array}{c}\text { Percentage } \\
\text { of houses } \\
\text { with at least } \\
\text { one lodger }\end{array}$ & $\begin{array}{c}\text { Mean number } \\
\text { of lodgers in } \\
\text { those houses } \\
\text { with any lodgers }\end{array}$ \\
\hline Cheapside sample & 76 & 5.1 & 30 & 13.3 & 2.5 \\
Tower Hill precinct (Aldgate) & 116 & 5.6 & 64 & 13.8 & 1.9 \\
\hline
\end{tabular}

SOURCE: LMA, COL/CHD/LA/04/01/004, 053, 062, 063, 102.

lodging households were just over a person smaller, while families were just under a person smaller; in Tower Hill, the disparity was similar.

As revealed in Table 5 , the presence of lodgers in the population of the Cheapside parishes and Tower Hill precinct seems to have been approximately similar, in terms of both the proportion of the population consisting of lodgers, and the proportion of houses accommodating them. ${ }^{35}$ Some lodgers in Cheapside were clearly wealthy individuals, and lodging households were occasionally wealthier than those of their hosts. For example, Gerard Townesend, bachelor and gentleman, was liable for a surtax and was described as a lodger of Wm Smith, barber, of St Mary le Bow, who was assessed at the basic rate; similarly, Sarah Cash, the widow of a doctor of physic, lodger, was assessed at a higher tax rate than her host, Seth Bull, in Tower Hill precinct. ${ }^{36}$ Taken together, these facts seem to belie the understanding of lodging as the province of poorer inhabitants unable or unwilling to secure leases or subtenancies. Table 6 shows that, in the Cheapside parishes, lodgers were more often grouped into households and families than living as lone individuals, possibly because of the relative economic standing of lodgers in the two sample areas. The availability of greater space within Cheapside houses may also have contributed to this pattern.

Significantly, there appears to be a distinction in the marriage duty assessments of our study areas between houses where multiple households were cohabiting, and where a household was co-residing with a lodging household. That is, in houses with more than one household, only some of the cohabiting households were specifically identified as lodgers. ${ }^{37}$ It is possible that the terms of such households' occupancy were ascertained at the time of the assessment, with those residing for short periods,

TABLE 6

LODGERS AS DOMESTIC GROUPS AND SINGLETONS IN CHEAPSIDE AND ALDGATE, 1695

\begin{tabular}{|c|c|c|c|c|c|c|c|c|}
\hline & \multicolumn{3}{|c|}{$\begin{array}{l}\text { Lodgers living as household } \\
\text { or family groups }\end{array}$} & \multicolumn{2}{|c|}{$\begin{array}{l}\text { Lodgers living } \\
\text { as singletons }\end{array}$} & \multicolumn{3}{|c|}{$\begin{array}{l}\text { Lodgers living as singletons } \\
\text { with servants }\end{array}$} \\
\hline & $\begin{array}{l}\text { Number } \\
\text { of groups }\end{array}$ & $\begin{array}{c}\text { Total } \\
\text { number } \\
\text { of lodgers }\end{array}$ & $\begin{array}{c}\text { Percentage } \\
\text { of all } \\
\text { lodgers }\end{array}$ & $\begin{array}{c}\text { Total } \\
\text { number } \\
\text { of lodgers }\end{array}$ & $\begin{array}{c}\text { Percentage } \\
\text { of all } \\
\text { lodgers }\end{array}$ & $\begin{array}{l}\text { Number } \\
\text { of groups }\end{array}$ & $\begin{array}{c}\text { Total } \\
\text { number } \\
\text { of lodgers }\end{array}$ & $\begin{array}{c}\text { Percentage } \\
\text { of all } \\
\text { lodgers }\end{array}$ \\
\hline Cheapside sample & 16 & 43 & 56.6 & 29 & 38.2 & 2 & 4 & 5.3 \\
\hline $\begin{array}{l}\text { Tower Hill } \\
\text { precinct (Aldgate) }\end{array}$ & 19 & 49 & 42.2 & 63 & 54.3 & 2 & 4 & 3.4 \\
\hline
\end{tabular}

SOURCE: LMA, COL/CHD/LA/04/01/004, 053, 062, 063, 102. 
or under informal conditions, being classed as 'lodgers' (perhaps in contrast to households co-residing under subtenancies). Where subsequent households were listed for a house in the marriage duty assessments without being identified as 'lodgers', there is no discernible pattern in their composition, wealth or social status: they could be small or large, could have married couples and children or adult siblings, could employ servants, and could be wealthier than the first household listed in the house. ${ }^{38}$ On the other hand, we have noted that lodging households in Cheapside were generally smaller than those households listed first in a house, although, again, their composition and wealth varied considerably.

Alongside multiple households and lodgers were numerous other co-residents of the houses in our sample regions, including servants, apprentices, journeymen, employees and 'partners'. There were also a small number of individuals identified as the recipients of charity, including pensioners, parish children and poor inmates. It is difficult to discuss these people, however, as they were evidently not identified with any consistency in the marriage duty assessments from parish to parish: in the Cheapside parishes, for example, only the assessment for St Mary le Bow explicitly identified such individuals. In the other parishes, as well as Tower Hill precinct (where only three inmates were identified), these poor individuals were presumably 'hidden' among those individuals listed within households without any discernable relationship to the household that they shared a house with. The actual collectors' returns for the marriage duty tax in our sample areas shed little further light on such people: only those for St Mary le Bow, among the Cheapside parishes, referred to payments made or due for these poorer inhabitants, while in Aldgate, a collectors' return covering a four-month period in 1706 was the only one that enumerated poor individuals in Tower Hill. ${ }^{39}$ There may well have been a correlation between the appearance of poorer residents in the records for St Mary le Bow and the fact that the parish was the least wealthy of the Cheapside sample. But it is surprising that poor individuals were not identified in greater numbers in the marriage duty assessment for Tower Hill, given the greater variety in the wealth and status, and more common poverty, of its population. It is possible that in the Aldgate area the larger number of poorer residents simply were not enumerated in the assessment, whereas those in St Mary le Bow were more carefully identified.

While not a great many individuals were identified as poor, in St Mary le Bow it is interesting to note that the households in which they were accommodated included some of the wealthiest in the parish. The majority of St Mary le Bow households hosting an inmate, pensioner, parish child or otherwise poor resident were assessed in 1695 at the basic rate, but there were a number liable for a surtax. James Rawlins, gentleman, for example, a householder cohabiting with the household of John Bakewell, book-keeper, sheltered the pensioner Elizabeth Howard. Similarly, Obediah Grevell, watchmaker, numbered Damerons Smith, inmate, among his household; and the grocer John Whiteing provided accommodation for Benjamin Whiting, an inmate and possibly a kinsman of some description. In the two latter cases, it is likely that the houses that these domestic groups occupied were among the most prestigious and substantial of the parish, as both accommodated a number of lodgers and bachelors rated for a surtax, suggesting high rent values. Those who were classed as poor in some fashion were predominantly female (although not necessarily widows) or 
children, and at least four households accommodated three or more seemingly unrelated such individuals. ${ }^{40}$

One house in St Mary le Bow is particularly interesting in terms of residents comprising poor inhabitants. Seemingly among the parish's larger houses, it accommodated: a man described as 'a servant' (the first listed individual in the houseful, apparently living separately from his master) with his wife and daughter; a female inmate; another female inmate with a daughter; a poor widow and her two sons; a washerwoman; and three parish children. ${ }^{4 \mathrm{I}}$ There appears to have been no 'householder' in any normal sense of the word living in this property, which raises questions about the parish's role in the support of these individuals, as well as the use to which the property was put.

Individuals designated 'inmate', however, may need to be viewed in a different light from the parish children, pensioners and poor, given that some of them in St Mary le Bow were assessed for a surtax in their own right. For example, the solicitor Edward Row and his wife Frances were described as inmates of Robert Johnson's household, yet Row was liable for a surtax; Johnson's occupation, meanwhile, was given as porter, and he was assessed at the basic rate. ${ }^{42}$ Similarly, inmates were sometimes listed with apprentices and servants of their own, ${ }^{43}$ in addition to spouses and children, while some were called 'poor inmate', perhaps to differentiate them formally from their wealthier counterparts. ${ }^{44}$

The housing of lodgers, inmates, the poor and temporary visitors to the parish, often in domestic groups in their own right, within houses occupied sometimes by more than one household, significantly contributed to the residential density and distinctly metropolitan character of the domestic unit in London. ${ }^{45}$ In terms of the use of space within these houses, and the domestic routines of their inhabitants, the degree of overlap is something that might usefully be investigated, especially in the light of the common perception of London's population being transient and highly mobile. How far the poor and strangers were integrated into the household activities of their hosts, how much they were financially supported by the householder and by the parish, and how far their status derived from the house in which they lived, are all questions the answers to which would help to illuminate the mechanisms of social structure in seventeenth-century London.

The final set of individuals living within London's households, the servants and apprentices, provides us with the clearest indicator of a social and economic contrast between the domestic groups of the city centre and the suburbs in I695. Distinguishing between servants and apprentices is somewhat problematic in the marriage duty assessments, as only St Mary le Bow from the Cheapside parishes explicitly referred to apprentices. The presence of apprentices is inferred in the other Cheapside parishes through a comparison of the 'servant' population in the Cheapside sample: in St Mary le Bow the proportion of the population composed of 'apprentices' and 'servants' combined was equal to the proportion of the population in the other three parishes composed of just 'servants'. Figure 3 reveals that just over a half ( 55 per cent) of Cheapside households listed no servants or apprentices, whereas in Tower Hill precinct the figure was 88 per cent. Meanwhile, Table 7 shows that over one-third of the population of the Cheapside parishes was composed of servants and apprentices, with every house, on average, accommodating over two servants or apprentices under 
its roof. In Tower Hill, by contrast, servants and apprentices made up less than one-tenth of the population, and fewer than one dwelling in two housed any. Large numbers of servants or apprentices (three or more) could be found in very few houses in Tower Hill, whereas it was not at all uncommon to find them in the Cheapside parishes (see Figure 3). ${ }^{6}$ The high numbers of servants and apprentices living in the Cheapside houses contributed to that area's population density in a way that was not the case in Tower Hill.
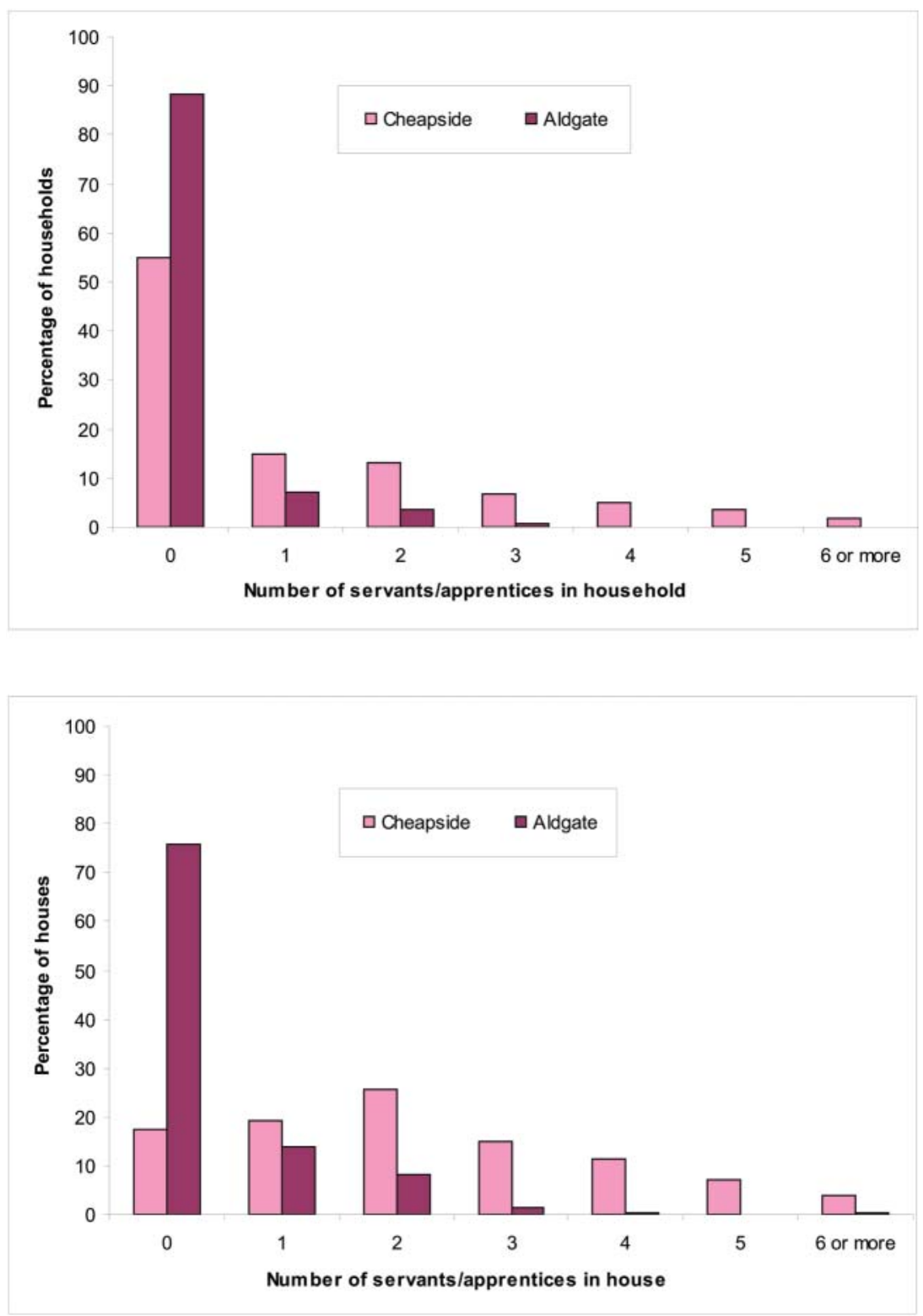

FIGURE 3 Numbers of servants and apprentices inhabiting households and houses in Cheapside and Aldgate, 1695. Source: LMA, COL/CHD/LA/04/01/004, 053, 062, 063, 102. 
TABLE 7

SERVANTS AND APPRENTICES IN CHEAPSIDE AND ALDGATE, 1695

\begin{tabular}{lccc}
\hline & $\begin{array}{c}\text { Total number of } \\
\text { servants/apprentices }\end{array}$ & $\begin{array}{c}\text { Percentage of } \\
\text { population }\end{array}$ & $\begin{array}{c}\text { Mean number of } \\
\text { servants/apprentices per house }\end{array}$ \\
\hline Cheapside sample & 503 & 34 & 2.2 \\
Tower Hill precinct (Aldgate) & 175 & 8.4 & 0.4 \\
\hline
\end{tabular}

SOURCE: LMA, COL/CHD/LA/04/01/004, 053, 062, 063, 102.

Here, we find one aspect of the relative structures of the domestic groups populating the city centre and suburban areas of London that shows a marked contrast, and that supports the centre/periphery model posited by some metropolitan historians. Many of the other aspects of household structure appear to be surprisingly similar across the two areas, but the case of servants and apprentices serves to highlight the precise nature of what differences there are (and, as we shall see in a later section on wealth, at least partially belie some of the emerging similarities): economic status did, indeed, affect the structure of London's early modern households. The following section considers whether this was also the case with the families within our respective study areas.

\section{The family}

Historians have debated whether or not the early modern period witnessed the transition of the family unit from a traditional form to a modern form, or indeed whether there were any structural changes to the size or composition of the family group. ${ }^{47}$ The demographic upheavals at work in seventeenth-century London and the pressures that they brought to the city's domestic groups were seen by contemporaries to threaten the stability of the family, and consequently the fabric of the social order altogether. Broken, multiple and illegal marriages, sexual immorality and illegitimate and abandoned children were declaimed as pressing social threats. ${ }^{48}$ This 'atomisation' of the early modern metropolitan domestic unit has been seen as especially characteristic of the burgeoning suburban areas, where the bulk of London's population lived. ${ }^{49}$ Certainly, the parish clerks of St Botolph Aldgate in the early part of the seventeenth century frequently recorded in their memoranda books the biographical histories of those families who were deemed to be deserving of moral opprobrium, and in so doing painted a vivid picture of the breakdown of moral traditions in the parish. A clerk noted with scorn, for example, the christening of Abraham Haddock, reputedly the son of Israel Haddock and an unnamed single woman who gave birth in the street and then 'like a Base Strumpet Ranne away', leaving the child behind - a tactic copied by the father, 'who hath an honest wife of his owne, is Runne away from hir, like a base Varlet'. 'God send the Child more grace than the wicked parents' prayed the clerk. ${ }^{\circ}$

The issue of reputation was at the forefront of the social aspects of households and families, and, indeed, 'reputed' is a term that appears frequently throughout Aldgate's memoranda books, often when the character of husbands and wives is being discussed. Marriage was seen by contemporaries as particularly under threat, not 
least because, in London's densely populated parishes, the legality of marriages was hard to police. The burial of a long sick 30-year-old sailor lying at the house of the widow Jone Blounstone in Aldgate's Swan Alley raised parochial eyebrows: 'The said Jone Blounstone kept him at her howse, and said he was her husband but I have heard sence that it was not trewe', recorded the inquisitive parish clerk. ${ }^{5 \mathrm{I}}$ The breakdown of marriage, and the consequent fragmentation of the family and, by extension, society, was at the root of contemporary concerns about the changing domestic experience of London's population. Sexual immorality was seen to be rife, leading to parliamentary acts and national campaigns to halt the perceived slide into chaos, and to a literary culture redolent with sexual intrigue and deceit. ${ }^{52}$ Masters were worried that their servants were intermittently 'moonlighting' as whores, or were being unwittingly seduced away from their household to become whores; women were seen wandering London's streets, revelling in the extra social and domestic freedoms that the metropolis afforded them (and thereby threatening the social order underpinned by the household). ${ }^{53}$ The complexity of life in the city was reflected in the ambiguities surrounding marriage and the relationships between men and women: there seem to have been many complex types of relationships between men and women, many of which were socially acceptable within certain public spheres. ${ }^{54}$ In Aldgate, however, the union of certain individuals prompted the indignation of the parish clerks. Recording the marriage of William Dennis and Joane Wellar, a clerk added that 'The Bride was a peece of Crackt Stuff'; when Thomas Grove married Katherine King, it was noted that Grove had 'continued a widower almost vj weekes'; and there were several marriages that took place scant weeks before a christening was performed for the newlyweds. ${ }^{55}$ Contemporary recognition of the apparent increase in fraudulent marriages is reflected in the provisions of the Marriage Duty Act itself, which explicitly included 'seemingly' married couples within the list of those liable to the tax: 'any other persons who shall cohabitt and live together as man and wife shall and are hereby made lyable to pay ... according to their respective degrees ... as they ought to have paid by virtue of this Act if they had been married according to the Law of England'. ${ }^{56}$

Turning to our sample areas, Table 8 shows that, in I695, almost one-quarter of houses in both areas accommodated no married couples, while two-thirds housed one and a small number more than one. Again, the similarity in the pattern across the two regions is noteworthy, there being a slight divergence in the case of four cohabiting married couples (again, presumably a consequence of the more spacious houses in Cheapside).

TABLE 8

PERCENTAGES OF HOUSES ACCOMMODATING MARRIED COUPLES IN CHEAPSIDE AND ALDGATE, 1695

\begin{tabular}{lccccc}
\hline & \multicolumn{5}{c}{ Number of married couples in the house } \\
\cline { 2 - 6 } & $\mathbf{0}$ & $\mathbf{1}$ & $\mathbf{2}$ & $\mathbf{3}$ & $\mathbf{4}$ \\
\hline Cheapside sample & 22.7 & 67.6 & 8 & 0.9 & 0.9 \\
Tower Hill precinct (Aldgate) & 23.2 & 67.5 & 8.2 & 0.9 & 0.2 \\
\hline
\end{tabular}

SOURCE: LMA, COL/CHD/LA/04/01/004, 053, 062, 063, 102. 
A much starker, and perhaps surprising, figure is the proportion of families that included no married couples. Analysis of the marriage duty assessments reveals that 50 per cent of families in Tower Hill, and 54.6 per cent of families in Cheapside, were composed of either single-parent families, sibling partnerships or other unidentified kinship relationships that did not comprise a husband and wife. Similarly, exactly half of Aldgate's households were not headed by a married couple, while the same was true for 53.6 per cent of Cheapside's households. ${ }^{57}$

Another unexpected finding - depicted in Figure 4 - is the contrast in the proportion of unmarried adults in the population between the Cheapside and Aldgate areas: in the former, 34.5 per cent of the adult population, including servants, were married, whereas in Aldgate the figure was higher, at 55.2 per cent. If we exclude servants from the adult population, the respective married proportions would be 55.I per cent and 78.4 per cent, respectively. These figures contradict the accepted pattern of population distribution across city and suburban areas, where the proliferation of unmarried individuals is normally seen as a corollary of poorer parishes..$^{8}$

The presence of 'lone householders' living in the Cheapside and Aldgate sample areas is shown in Table 9 to be roughly equivalent. The fact that one-third of households comprised a single individual in both districts strongly suggests an atomised society; but what is equally clear is that the picture is not a simple one. Economic factors (along with the character of housing and the built environment) were involved in the formation of domestic units, and while some of the patterns may appear to have been similar between Cheapside and Aldgate, the driving forces behind them

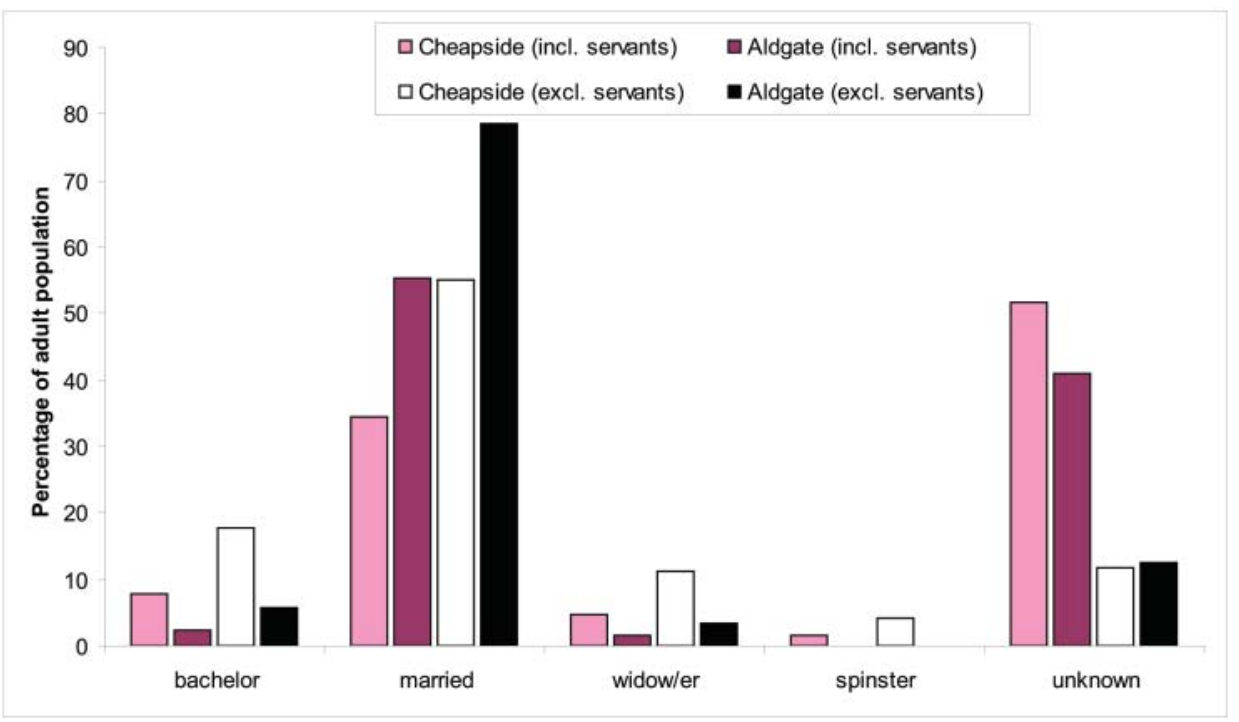

FIGURE 4 Proportion of the adult population (including and excluding servants) by marital status in Cheapside and Aldgate, 1695. Source: LMA, COL/CHD/LA/04/01/004, 053, 062, 063, 102. The category 'unknown' consists of all those individuals whose marital status is not explicitly stated in the assessments, and who therefore do not appear in the other four categories. 
TABLE 9

LONE HOUSEHOLDERS IN CHEAPSIDE AND ALDGATE, 1695

\begin{tabular}{lcc}
\hline & $\begin{array}{c}\text { Lone householders (without servants) } \\
\text { as percentage of all households }\end{array}$ & $\begin{array}{c}\text { Lone householders (employing } \\
\text { servants) as percentage of all } \\
\text { households }\end{array}$ \\
\hline Cheapside sample & 33.6 & 8.6 \\
Tower Hill precinct (Aldgate) & 36.8 & 1.6 \\
\hline
\end{tabular}

SOURCE: LMA, COL/CHD/LA/04/01/004, 053, 062, 063, 102.

may well have been different. Although we will return to this subject at greater length below, the analysis of lone householders is a case in point: Table 9 shows that householders living alone in Cheapside were five times more likely to be dwelling with servants than those in Aldgate, a situation that illustrates clear differences between the two regions.

Where families in our sample areas shared houses in I695, they had, for the most part, the 'simple' familial structure identified by Laslett as the norm throughout England. As is clear from Table ro, very few families contained any resident extended kin (adult siblings, aunts/uncles, nephews/nieces, cousins, etc.), and even fewer enjoyed the presence of a third generation. ${ }^{59}$ The proportion of non-nuclear families is comparable across the city-centre and suburban areas. The fact that almost Io per cent of families in Cheapside may have included kinship relationships outside of the immediate conjugal unit is interesting, however, as it points to the more complex composition of domestic groups in the capital's central areas than in the suburbs. ${ }^{60}$

The perceived wisdom regarding the defining characteristic of late seventeenthcentury London families, and an anxious complaint of contemporaries, is that they lacked the numbers of children of their provincial counterparts. ${ }^{61}$ Nevertheless, some historians have argued against this: for example, Schurer has found similar patterns of the presence of children in households in both London and rural Wiltshire, and has suggested that the distinction between urban and rural households is not a clear one. ${ }^{62}$ In addition, some scholars have argued that the low numbers of children listed in seventeenth-century London households are attributable to the compilation of the city's taxation lists. ${ }^{63}$ Here, the distinction between the richer city-centre parishes

TABLE 10

EXTENDED AND THREE-GENERATION FAMILIES IN CHEAPSIDE AND ALDGATE, 1695

\begin{tabular}{|c|c|c|c|c|c|}
\hline \multirow[t]{2}{*}{ Area } & \multirow[t]{2}{*}{ otal families } & \multicolumn{2}{|c|}{ Extended families } & \multicolumn{2}{|c|}{ Three-generation families } \\
\hline & & Definite & Definite + possible & Definite & Definite + possible \\
\hline Cheapside sample & 436 & 14 & 40 & 1 & 4 \\
\hline Percentage of all Cheapside families & & 3.2 & 9.2 & 0.2 & 0.9 \\
\hline Tower Hill precinct (Aldgate) & 808 & 42 & 42 & 1 & 13 \\
\hline Percentage of all Aldgate families & & 5.2 & 5.2 & 0.1 & 1.6 \\
\hline
\end{tabular}

SOURCE: LMA, COL/CHD/LA/04/01/004, 053, 062, 063, 102. Possible denotes where the evidence suggests extended or three-generation family groups, but is not explicit. 
and the poorer suburban areas has also been made, with the former seeing smaller numbers of children than the latter, although, again, opinion is divided on this. ${ }^{64}$

Table I I shows that children constituted a relatively small proportion of the population in both of our study areas, more so in the case of the Cheapside parishes fewer children are, indeed, evident in the wealthy city-centre parishes. One explanation for this phenomenon may lie in the large numbers of servants and apprentices in the Cheapside households, which not only 'bulk out' the population, thus reducing the proportion composed of children, but which are also the section of the population who are least likely to be having children. Another possible factor may be the propensity and resources within a fairly prosperous area to send infants to be nursed elsewhere in healthier climes. Family reconstitution work using the registers of the Cheapside parishes has shown that many of the families appearing in the marriage duty assessments did, in fact, have more children than are listed. A number of these 'missing' children died shortly before the assessment was made, while other, recently baptised, children are simply not listed in the assessment, possibly because they were living elsewhere. ${ }^{65}$

As revealed in Figure 5, the wealthier households in Cheapside seem to have had larger numbers of children than their neighbours rated at the basic level for the marriage duty assessment; Cheapside householders liable for the basic rate were also over twice as likely to have no children as their wealthier counterparts. In Tower Hill precinct, the picture is slightly different, as larger numbers of children (more than three) were only found in households assessed at the basic rate.

In both sample areas, the majority of families included no children, which certainly sits well with contemporary perceptions, as does the fact - shown in Table I2 — that almost one-quarter of families with children were headed by single parents. ${ }^{66}$ Although having low numbers of children has been identified as characteristic of domestic units across the city, it is perhaps noteworthy that the figures for Cheapside and Aldgate are so close - one might expect greater disparity, given the different conditions at work in the two areas. In Aldgate at the start of the seventeenth century, conditions for children seem to have been precarious, with high numbers of infant deaths, stillborn births, infanticides, foundlings, and premature and illegitimate children abandoned to the charity of the parish. Illegitimate children being born to servants illicitly in other people's houses seems to have been something of a common occurrence, as judged by the repeated attention it draws in the parish clerks'

TABLE 11

CHILDREN IN CHEAPSIDE AND ALDGATE, 1695

\begin{tabular}{lcccccc}
\hline & $\begin{array}{c}\text { Total number } \\
\text { of children }\end{array}$ & $\begin{array}{l}\text { Percentage } \\
\text { of population }\end{array}$ & $\begin{array}{c}\text { Mean children } \\
\text { per house } \\
\text { having any } \\
\text { children }\end{array}$ & $\begin{array}{c}\text { Mean children } \\
\text { per family } \\
\text { having any } \\
\text { children }\end{array}$ & $\begin{array}{c}\text { Percentage } \\
\text { of houses } \\
\text { with no } \\
\text { children }\end{array}$ & $\begin{array}{c}\text { Percentage } \\
\text { with no } \\
\text { children }\end{array}$ \\
\hline Cheapside sample & 299 & 20.2 & 2.2 & 1.9 & 39.6 & 64.2 \\
$\begin{array}{l}\text { Tower Hill precinct } \\
\text { (Aldgate) }\end{array}$ & 613 & 29.4 & 2 & 1.9 & 34.2 & 60.3 \\
\hline
\end{tabular}

a The figure is 1.3 for both Cheapside and Aldgate if all houses (i.e. including those with no children) are taken into account. ${ }^{b}$ The figures are 0.7 for Cheapside and 0.8 for Aldgate if all families (i.e. including those with no children) are taken into account. SOURCE: LMA, COL/CHD/LA/04/01/004, 053, 062, 063, 102. 


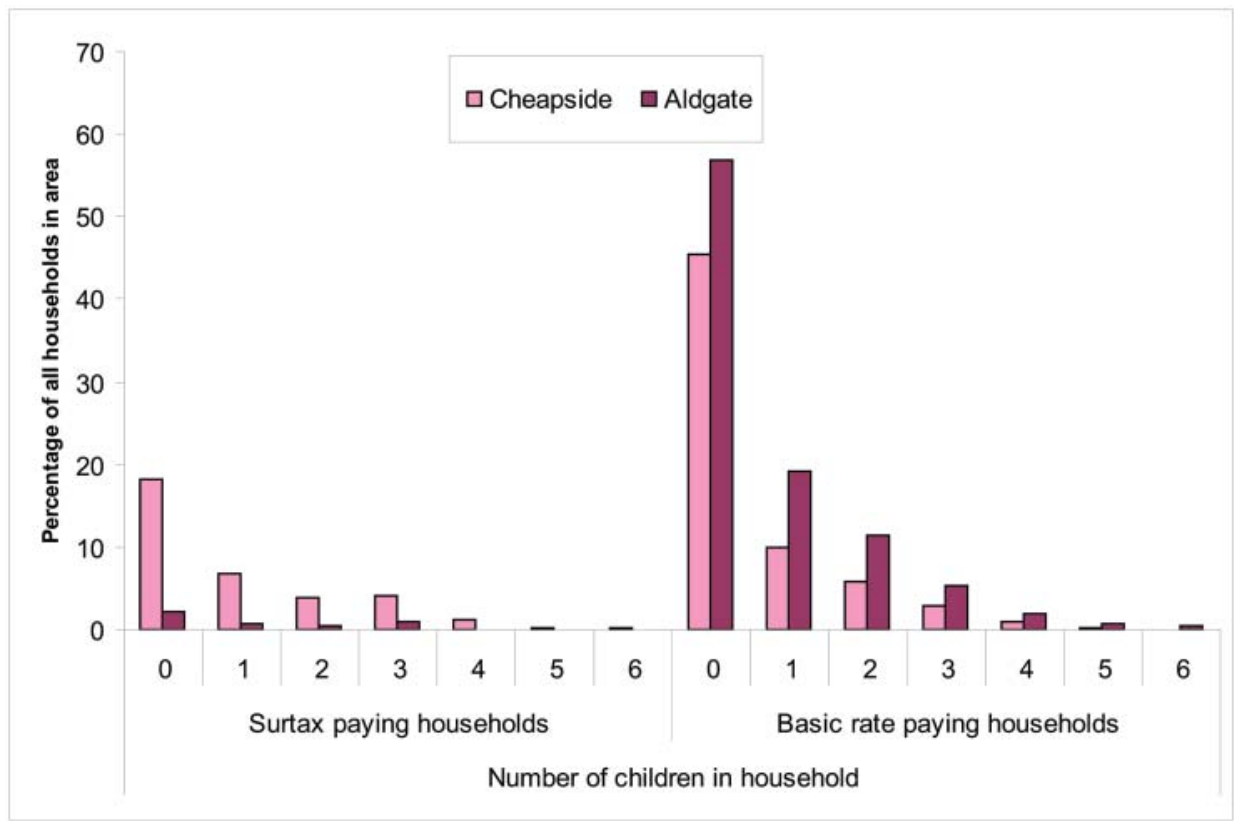

FIGURE 5 Proportion of households with children in Cheapside and Aldgate by the status of household, showing number of children in household, 1695. Source: LMA, COL/CHD/ LA/04/01/004, 053, 062, 063, 102. Total number of households: Cheapside, 428, Aldgate, 807; both sample areas omit one household that was unrated.

TABLE 12

CHILDREN AND SINGLE-PARENT FAMILIES IN CHEAPSIDE AND ALDGATE, 1695

\begin{tabular}{lcc}
\hline & Percentage of families with children & $\begin{array}{c}\text { Percentage of those families with } \\
\text { any children that are headed by a } \\
\text { single parent }\end{array}$ \\
\hline Cheapside sample & 35.8 & 23.1 \\
Tower Hill precinct (Aldgate) & 39.7 & 21.8 \\
\hline
\end{tabular}

SOURCE: LMA, COL/CHD/LA/04/01/004, 053, 062, 063, 102.

memoranda. ${ }^{67}$ Many of Aldgate's infants, disadvantaged by the 'fragmentation' of the traditional family unit, were placed in the homes of elderly parishioners at the parish's expense. ${ }^{68}$

\section{Wealth and social status}

As mentioned previously, economic conditions shaped the formation of early modern London's domestic units, and where differing economic conditions prevailed across different areas, one might expect to see structural differences in the households and families of those areas. Indeed, London provides a good testing ground for this thesis: 
historians have long been aware that the scale and variety of its inhabitants' wealth is at the heart of how the capital differs from the rest of the country. Cheapside and Tower Hill, in accordance with the centre/periphery model, had different economic profiles: the former was largely wealthy, and the latter was largely poor, although we have seen that the division was not a simple one. Nevertheless, by examining those areas' domestic groups from an economic perspective, we can gain a clearer understanding of the social contexts of such groups.

If we begin with the individuals who were living alone, or living in households without any discernible kin relationship to any of the other residents, then the differences between our city and extramural sample areas begin to emerge with more definition. The presence of widows in households, for example, suggests some variation in the respective characteristics of the two regions. Although these individuals are clearly under-represented or under-identified in the marriage duty assessments, they are more of a feature of the population in the richer Cheapside parishes than in the suburb of Tower Hill: Io per cent of households in Cheapside accommodated a widow, whereas less than one per cent of households in Aldgate had an identifiable widow. ${ }^{69}$ The reasons behind this are likely to be at least partly affected by economic factors: Cheapside inhabitants were more likely to be relatively wealthy individuals, with active commercial interests that had brought them to the city centre in the first place. Such people may have had the wherewithal to afford to remain in the area after widowhood. It is also possible that many of the residents along Cheapside were holding long-term leases at very favourable rents, as a consequence of the rebuilding after the Fire, which again meant that they could survive the potential financial pressures of widowhood. Of course, not all widows were poor, but in Aldgate the majority of the parish's residents were not wealthy, and widows may have found themselves leaving the area in search of cheaper housing. Only four of Aldgate's widows were liable for a surtax in the marriage duty assessments, whereas that applied to four times as many widows in the Cheapside parishes. ${ }^{70}$

With regard to younger single people living in the sample areas (if we may blithely conceive of our widows and widowers as 'older' single people), the characteristics are again suggestive of the relative social and economic conditions at work on the domestic group. Table $\mathrm{I}_{3}$ shows that in Cheapside just under one-third of all dwellings contained one or more bachelors, whereas only 6.7 per cent of Aldgate

TABLE 13

BACHELORS IN CHEAPSIDE AND ALDGATE, 1695

\begin{tabular}{lccccc}
\hline & $\begin{array}{c}\text { Percentage of } \\
\text { houses with } \\
\text { one or more } \\
\text { bachelors }\end{array}$ & $\begin{array}{c}\text { Percentage of } \\
\text { total households } \\
\text { hosting } \\
\text { any bachelors }\end{array}$ & $\begin{array}{c}\text { Percentage of } \\
\text { households } \\
\text { hosting any } \\
\text { bachelors whose } \\
\text { heads were } \\
\text { assessed for } \\
\text { a surtax }\end{array}$ & $\begin{array}{c}\text { Percentage of } \\
\text { bachelors } \\
\text { assessed } \\
\text { for a surtax }\end{array}$ & $\begin{array}{c}\text { Bachelors as } \\
\text { percentage of } \\
\text { total population } \\
\text { (excluding } \\
\text { children, } \\
\text { servants and } \\
\text { apprentices) }\end{array}$ \\
\hline Cheapside sample & 29.8 & 18.2 & 60.3 & 38.5 & 17.87 \\
$\begin{array}{l}\text { Tower Hill precinct } \\
\text { (Aldgate) }\end{array}$ & 6.7 & 4.2 & 8.8 & 8.6 & 5.7 \\
\hline
\end{tabular}

SOURCE: LMA, COL/CHD/LA/04/01/004, 053, 062, 063, 102. 
TABLE 14

WEALTH AND STATUS IN CHEAPSIDE AND ALDGATE, 1695

\begin{tabular}{lccc}
\hline & $\begin{array}{c}\text { Percentage of households } \\
\text { headed by 'partners' }\end{array}$ & $\begin{array}{c}\text { Percentage of households } \\
\text { whose heads were } \\
\text { assessed for a surtax }\end{array}$ & $\begin{array}{c}\text { Percentage of houses } \\
\text { occupied by more than } \\
\text { one household with } \\
\text { differing status ratings }\end{array}$ \\
\hline Cheapside sample & 2.2 & 33.8 & 51.6 \\
Tower Hill precinct (Aldgate) & 0 & 4 & 6.9 \\
\hline
\end{tabular}

SOURCE: LMA, COL/CHD/LA/04/01/004, 053, 062, 063, 102.

houses did. Again, in Cheapside the majority of households accommodating bachelors fell into the surtax status bracket, whereas there were only three such households (8.8 per cent) housing bachelors in Aldgate. With regard to the bachelors themselves, over one-third of Cheapside's bachelors were assessed for a surtax, whereas less than Io per cent of Aldgate's were. Bachelors in Cheapside were almost as likely to be rich young men as not: the same was in no way true of Aldgate's.

The presence of apprentices might further emphasise the impact of social and economic factors on the study areas, if only the evidence from the marriage duty assessments was less problematic. ${ }^{71}$ Only four per cent of households in Tower Hill explicitly indicated the presence of apprentices, whereas the proportion in St Mary le Bow was 22.7 per cent. ${ }^{72}$ Again, many of the Cheapside apprentices were identified as the sons of men liable for a surtax (and thus assessed at higher than the basic rate themselves), unlike the Aldgate sample, suggesting that the economic standing of the young single men in the two areas was considerably different. ${ }^{73}$

If we broaden the analysis to look at issues of wealth and status more generally, something that the evidence of the marriage duty assessments is well suited to, ${ }^{74}$ then many of the expected differences in the respective populations do indeed become evident. For example, Table I4 shows that one-third of households in Cheapside were headed by an individual subject to a surtax, but only four per cent of Aldgate households were. A further case in point might be those households whose heads were two individuals described as 'partners', implying some kind of commercial endeavour; five of these existed in the Cheapside parishes, but they did not exist at all in Tower Hill precinct. $^{75}$

Similarly, the relative wealth of the lodgers in the two areas suggests different reasons for taking up (presumably temporary, although not necessarily short-term ${ }^{76}$ ) lodgings in the city centre and the suburbs. As Table ${ }_{5} 5$ reveals, while less than one per cent of lodging individuals were assessed for a surtax in Aldgate, the proportion was seven times higher for Cheapside. ${ }^{77}$ However, a greater proportion of the adult population was composed of lodgers in the Aldgate area.

\section{Conclusions}

The foregoing analysis would be difficult to perform with a source other than the marriage duty assessments, with their detailed depiction of the residents of individual houses, their wealth, status and qualities, their position in the life-cycle and, more 
TABLE 15

LODGERS AND THEIR WEALTH IN CHEAPSIDE AND ALDGATE, 1695

\begin{tabular}{lccr}
\hline & Status rating & $\begin{array}{c}\text { Lodgers as percentage of } \\
\text { total adult population }\end{array}$ & Percentage of lodgers \\
\hline Cheapside sample & Basic & 11.6 & 92.6 \\
& Surtax & 0.9 & 7.4 \\
Tower Hill precinct (Aldgate) & Basic & 18.2 & 99.1 \\
& Surtax & 0.2 & 0.9 \\
\hline
\end{tabular}

SOURCE: LMA, COL/CHD/LA/04/01/004, 053, 062, 063, 102.

especially, the nature of the relationships between them. The complexity of London's domestic groups is made manifest in these listings to an extent that is only partially reflected in the other taxation records of the period; and this complexity, in turn, highlights the necessity for a metropolitan-specific approach to identifying and classifying those groups. Much of what has been written about the early modern household and family has been founded on analyses of less informative sources, and work on London, in particular, has tended to draw upon methodological approaches that, while well suited to studies of simpler provincial household forms, often struggle to cope with those found in the capital. In this sense, the historical perception of the early modern metropolitan household and family has been built on less than secure foundations.

The methodology presented here re-addresses the issue of the particularity of the structure of the metropolitan domestic group, by enabling us to examine the forms of household and family while maintaining the subtle distinctions in the identification of 'types' of individuals made by the source compilers. In utilising this approach, we have presented a number of findings, some of which confirm, and some of which argue against, the received wisdom with regard to the composition of London's households, particularly those that depict a strong contrast between London's wealthy central commercial districts and poorer extramural areas. Our comparison of innercity Cheapside parishes with the suburban precinct of Tower Hill, for example, has reinforced the traditional pattern of the social topography of seventeenth-century London, in terms of the economic standing of the two areas. We have also seen that the wealth of the respective inhabitants of each region directly contributed to some of the generally observed patterns of population distribution and domestic organisation, with larger households containing more apprentices, servants and bachelors being characteristic of the central area.

But beyond these standard patterns, we have revealed a number of unexpected structural similarities. The manner in which many people lived in the central and suburban areas was surprisingly alike, in terms of both the proportion of dwellings housing co-resident households and the level of lodging within their overall populations. The family units in both regions were of equivalent size, and contained comparable numbers of children. On all these points, the similarities in the domestic experience of the two areas are more numerous than we might expect. Moreover, it was the city-centre parishes, not the burgeoning suburban area, which housed the higher proportion of unmarried individuals and single-parent families. All this 
may cause us to rethink some of our accepted wisdoms regarding household and family structure in late seventeenth-century London, for it is only by analysing the metropolitan domestic group at different levels that we can hope to advance our understanding of the patterns and processes at work in this area.

\section{Notes}

I This article is based on research undertaken during a three-year research project funded by the AHRC, 'People in place: families, households and housing in early modern London', a collaborative venture between Birkbeck, University of London, the Centre for Metropolitan History at the Institute of Historical Research, and the Cambridge Group for the History of Population and Social Structure at the University of Cambridge. Full details of the project and its outputs can be found at: http://www. history.ac.uk/cmh/pip/index.html

2 P. Laslett with R. Wall (eds), Household and Family in Past Time (Cambridge, I972), especially Laslett, 'Introduction: The History of the Family', $\mathrm{I}-89$, and Laslett, 'Mean Household Size in England Since the Sixteenth Century', I25-58. See Laslett, 'Mean Household Size', I26 for national mean household size as 4.75 or less between the end of the sixteenth and the beginning of the twentieth century.

3 R. Wall, 'Regional and Temporal Variations in English Household Structure From I650', in J. Hobcraft and P. Rees (eds), Regional Demographic Development (I979), 89-II3, on I02, I06, I09 (quotation); for comparable sentiments, see K. Schurer, 'Variations in Household Structure in the Late Seventeenth Century: Towards a Regional Analysis', in K. Schurer and T. Arkell (eds), Surveying the People (Oxford, I992), 253-78, on 272.

4 See Table 2 for mean houseful figures for London in I695, ranging between 4.5 and 6.6. By contrast, mean houseful size in areas outside of London in the period I695-I705 was, at its highest, only fractionally above the lowest figure for London: Bristol (seven parishes), 3.9; East Kent (II parishes), 4.7; Shrewsbury (I2 wards), 4.5; Southampton (five parishes), 4; East Wiltshire (six parishes), 3.9 (Schurer, 'Variations in Household Structure', 268).

5 Under the Cambridge Group's scheme, for instance, conjugal family units of 'inmates' (all those deemed to have only a casual connection with a household) are not regarded as true households, and their heads are not regarded as household heads on a par with others (Laslett, 'Introduction', 39). See also the remarks of Jeremy Boulton in 'The Poor Among the Rich: Paupers and the Parish in the West End, I600-I724', in P. Griffiths and M. S. R. Jenner (eds), Londinopolis (Manchester and New York, 2000), I97-225, on 206.
6 Glass clearly recognised the need to assign the inhabitants of a house to separate co-resident household units, but was unduly pessimistic about the procedure. See D. V. Glass (ed.), London Inhabitants Within the Walls, I695 (London Record Society, 2, I966), xxviii-xxxii. Spence does employ such a distinction, but it is limited to a division between a principal and lodging household, thereby precluding the possible existence of co-resident households of a more permanent nature and equal status. See C. Spence, London in the I690s (2000), 89-90.

7 For example, see F. Dabhoiwala, 'The Pattern of Sexual Immorality in Seventeenth- and EighteenthCentury London', in Griffiths and Jenner, Londinopolis, 86-I06; and L. Gowing, “"The Freedom of the Streets": Women and Social Space, I560-I640', in Griffiths and Jenner, Londinopolis, I30-5I.

8 For the lack of social exclusivities within the parishes of early modern London, see E. Jones, 'London in the Early Seventeenth Century: An Ecological Approach', London Journal, 6 (I980), I23-33; and Boulton, 'Poor Among the Rich', I98, 2I3. The distinction between east and west London is made in M. J. Power, 'The East and the West in Early Modern London', in E. W. Ives, R. J. Knecht and J. J. Scarisbrick (eds), Wealth and Power in Tudor England (1978), I67-85, while G. Sjoberg, The Pre-Industrial City (New York, I960), provides the classic statement of the concentric circle model. Derek Keene has posited a more complex model of London's social topography, describing concentric circles emanating from two focal points of metropolitan commerce, the city and the Strand, where 'Land values and [building] density declined with distance from these poles, on a concentric pattern which emphasised an increasing contrast between the wealthy districts and their peripheries'. See Keene, 'Growth, Modernisation and Control: The Transformation of London's Landscape, c.I500c.I760', in P. Clark and R. Gillespie (eds), Two Capitals (Oxford, 200I), 7-37, on I7.

9 See P. E. Jones and A. V. Judges, 'London Population in the Late Seventeenth Century', Economic History Review, 6 (1935-1936), 45-63, Table 3, for houseful sizes and percentages of parish populations liable to a surtax under the marriage duty assessment. Glass intermittently discusses the relationship between household structure and social 
status in London Inhabitants, xxv-xxxv, whereas Spence largely examines the two issues separately. See Spence, London in the I690s, 75-IOI.

Io For example, see Glass, London Inhabitants, xxv; and Spence, London in the I690s, 93, 97-9.

II Jones and Judges, 'London Population', 48; J. Alexander, 'The City Revealed: An Analysis of the I692 Poll Tax and the I693 4s. Aid in London', in Schurer and Arkell, Surveying the People, I8I-200, quotation on 185 . Glass follows the contemporary political arithmetician Gregory King in estimating the under-enumeration of the marriage duty assessments at between 7 and Io per cent. See Glass, London Inhabitants, $\mathrm{xxv}-\mathrm{xxviii}$.

${ }^{12}$ For a detailed discussion of the marriage duty assessments and their surcharge categories, see Glass, London Inhabitants, ix-xviii; and T. Arkell, 'An Examination of the Poll Taxes of the Later Seventeenth Century, the Marriage Duty Act and Gregory King', in Schurer and Arkell, Surveying the People, I42-77, on I63-7I.

${ }^{13} 6 \& 7 \mathrm{Wm}$ and M., c. 6: Statutes of the Realm, VI, I685-94 (I8I9), 568-89, on 574.

${ }^{\mathrm{I} 4}$ Glass, London Inhabitants, on $\mathrm{xv}-\mathrm{xvi}$, xviii-xix, and xxxviii, discusses the nature of the London assessments, and provides a name index of all those listed as living within the walls in I695 on I-332.

${ }^{15}$ This is the domestic group that Laslett and the Cambridge Group treated as the household. See Laslett, 'Introduction', 24, 39-40; and Laslett, 'Mean Household Size', I33-4. The reasons for our dissension from this definition are explained later in the section, but it is noteworthy that Richard Wall highlighted possible problems with the Cambridge Group's definition as early as I972. See R. Wall, 'Mean Household Size in England From Printed Sources', in Laslett with Wall, Household and Family, I59-203, on I6I-4.

${ }^{16}$ The rules and presumptions used in classifying the internal composition of the houseful will appear in full in a forthcoming publication in the Centre for Metropolitan History's working papers series.

${ }^{17} \mathrm{LMA}, \mathrm{COL} / \mathrm{CHD} / \mathrm{LA} / \mathrm{O}_{3} / 60 / 3$, f. I9.

${ }^{18}$ See the comments in note $\mathrm{I} 5$, above, and sources cited there.

I9 For recognition of this latter point, see Laslett, 'Introduction', 38; Wall, 'Mean Household Size', I59-66; Schurer, 'Variations in Household Structure', 272, n. 39; and Boulton, 'Poor Among the Rich', 206. The analysis of London's domestic groups presented here draws upon definitions that have been intended to maximise the potential for comparative analyses.

${ }^{20}$ Spence, London in the I690s, 48-54, especially Figure 3.4; Keene, 'Growth, Modernisation and Control', I7-I9.

${ }^{21}$ In 1695 , the mean population density of the four Cheapside parishes was 22I persons per acre, while in St Botolph Aldgate, it was 204 persons per acre; see Jones and Judges, 'London Population', 58, 60-2. Vanessa Harding suggests, however, that because of the larger, high-rise houses in Cheapside, in terms of the occupied floor-space Aldgate was, in fact, the more densely settled district. See V. Harding, 'Families and Housing in Seventeenth-Century London', Parergon, 24 (2007), II 5-38, on I 20.

${ }^{22}$ For the poverty of St Botolph Aldgate, see I. W. Archer, The Pursuit of Stability (Cambridge, I99I), I3, 64, I5I, I62, I84-92; and E. M. Tomlinson, A History of the Minories, London (1907), 353-80; in 1582 , for example, only I8 per cent of Portsoken ward householders paid subsidy. For a more detailed overview of the social and economic characteristics of the two study areas, see Harding, 'Families and Housing', II5-I6, II8-20, I30-3. Harding argues that approximately four-fifths of London's population lived outside the walls by I695. See Harding, 'Families and Housing', I30. Keene suggests that, by 1700 , two-thirds of the metropolitan population lived beyond the city's jurisdiction, and of those who lived within the city, half lived without the walls. See Keene, 'Growth, Modernisation and Control', 8.

${ }^{23}$ City districts were predominantly 'financial, commercial, retail and high-quality finishing', while extramural areas were predominantly manufacturing. See Keene, 'Growth, Modernisation and Control', I5.

${ }^{24}$ Keene, 'Growth, Modernisation and Control', 9-I 5 , 2I; Harding, 'Families and Housing', I2I, I23, I33. For the medieval origins of London's house forms and subsequent developments, see J. Schofield, The Building of London from the Conquest to the Great Fire (1984); and F. Brown, 'Continuity and Change in the Urban House: Developments in Domestic Space Organisation in Seventeenth-Century London', Comparative Studies in Society and History, 28 (I986), 558-90.

${ }^{25}$ For numerous references to current and prospective tenants petitioning for future leases, see D. Keene and V. Harding, Historical Gazetteer of London Before the Great Fire, vol. I, Cheapside (Cambridge, I987); and M. Carlin, 'St Botolph Aldgate Gazetteer' (typescript, Institute of Historical Research, London, 1987).

${ }^{26}$ See Tomlinson, History of the Minories, I82; and T. Forbes, Chronicle from Aldgate (New Haven and London, I97I), 3 .

${ }_{27}$ Harding, 'Families and Housing', I33. Parts of the marriage duty assessment for Tower Hill suggest single room occupancy by lone individuals, couples or, indeed, families. See LMA, COL/CHD/LA/o4/oI/ I02, ff. I67 and I92. Spence identified a concentric pattern of residential density, with domestic groups being smaller the further one moved away from the centre of the city. See Spence, London in the I690s, $45^{-8,} 64$. 
${ }^{28}$ This figure is arrived at by excluding the nine London parishes from Laslett's Ioo parish study. See Laslett, 'Mean Household Size', Table 4.I, where the term 'household' is used to describe what we mean by 'houseful'.

29 Archer, Pursuit of Stability, 215. For the role of the household in social life, see Gowing, 'Freedom of the Streets', I34; and Harding, 'Families and Housing', II7.

${ }^{30}$ M. Berlin, 'Reordering Rituals: Ceremony and the Parish, I520-1640', in Griffiths and Jenner, Londinopolis, 47-66, on 50-2.

${ }^{31}$ Forbes, Chronicle from Aldgate, 34. The Aldgate parish clerk likewise records a number of instances of women harbouring single women having children. See Forbes, Chronicle from Aldgate, I8-19. See also Archer, Pursuit of Stability, 76-8.

${ }^{32}$ In terms of the number of families per house in I695, the figure for Cheapside is exactly two, while for Tower Hill it is I.7.

33 Spence, for example, has argued that multiple occupancy of houses and the cohabitation of households was a characteristic of poorer areas; see Spence, London in the I69os, 48 , IоI.

${ }^{34}$ For a discussion of the latter issue, see Schofield, Building of London, I44-8; and J. Schofield (ed.), The London Surveys of Ralph Treswell (1987), 79-82. For the interrelationship between host and lodging groups within the physical spaces and domestic routines of the house, see Gowing, 'Freedom of the Streets', I36; and Harding, 'Families and Housing', I29, I35.

35 The work of historians such as Spence might have led us to expect a greater disparity between the two areas on the grounds of their contrasting economic character. See Spence, London in the I690s, 93, and his Table 4.5 and Figure 4.I3. In part of London's western suburb, the poll books show that about one-third of the population lodged in other people's houses; see Boulton, 'Poor Among the Rich', 206. The difference in the proportion of the population lodging in the present sample areas is likely to be the result of the distinction we make between 'lodgers' and 'cohabiters' (see above).

${ }^{36} \mathrm{LMA}, \mathrm{COL} / \mathrm{CHD} / \mathrm{LA} / 04 / 01 / 062$, f. 7; LMA, COL/ CHD/LA/O4/oI/IO2, ff. I35-6.

37 C.f. Spence and Harding, who identify all cohabitant households other than the first listed as lodging households in their analyses. See Spence, London in the I690s, 89-90; and Harding, 'Families and Housing', I29. In the present analysis, only those individuals and groups explicitly designated as 'lodgers' are treated as such; households and families listed after the first group in a house are not otherwise treated as a lodging group.

${ }^{38}$ For examples of the latter of these characteristics, see LMA, COL/CHD/LA/04/oI/004, f. 3; LMA, COL/CHD/LA/o4/oI/062, ff. 3, 4, 6, I3.
39 The collectors' returns record the actual baptisms, marriages and burials that occurred in the year and that fell under the remit of the marriage duty tax, as well as listing those bachelors and widowers who were liable for taxation. Three returns for St Mary le Bow (those for 1698-1699, I704-I705 and 1705I706) list a total of Io poorer individuals, all but one of them parish children or foundlings. See $\mathrm{LMA}, \mathrm{COL} / \mathrm{CHD} / \mathrm{LA} / \mathrm{o}_{3} / 30$; and LMA, COL/CHD/ $\mathrm{LA} / 03 / 36 / 4,5$. Eleven such residents are identified in Tower Hill between May and August I706. See $\mathrm{LMA}, \mathrm{COL} / \mathrm{CHD} / \mathrm{LA} / 47 / \mathrm{I} 5$.

${ }^{40} \mathrm{LMA}, \mathrm{COL} / \mathrm{CHD} / \mathrm{LA} / 04 / \mathrm{OI} / 062$, ff. I, 2, 3, 6, 7, I2, I4.

${ }^{4 I}$ Ibid., f. 2.

${ }^{42}$ Ibid., f. 2. For a brief note on the confusion surrounding the term 'inmate', see J. Boulton, Neighbourhood and Society (Cambridge, 1987), 36, n. 68.

43 Such as Thomas Ange, gilder, who is listed with his apprentice John Outon. See LMA, COL/CHD/ LA/04/0I/062, f. 7.

44 Ibid., f. 2, where the term 'poor inmate' is applied to both Mary Walton and Ann Bradley.

45 The sick (or insane) and the elderly who were unable to support themselves were often placed within the households of others. In the poorer Aldgate area, there is ample evidence of the parish sponsoring and organising these efforts. See Tomlinson, History of the Minories, 361; and Forbes, Chronicle from Aldgate, II6, II8, 2I4, 226.

${ }^{46}$ For comparative figures for the presence of servants and apprentices across London, see Spence, London in the 1690 , 95, $143^{-5}$.

${ }^{47}$ For an overview of these debates, see J. Sharpe, Early Modern England (1987), 56-76.

${ }^{4} 8$ See Gowing, 'Freedom of the Streets', and Dabhoiwala, 'Pattern of Sexual Immorality', for contemporary examples of concern at the moral and social ramifications of the collapse of the family. See also P. Earle, A City Full of People (1994), I56-65; M. R. Hunt, 'Wife Beating, Domesticity and Women's Independence in Eighteenth-Century London', Gender and History, 4 (1992), IO-33; and V. Fildes, 'Maternal Feelings Re-Assessed: Child Abandonment and Neglect in London and Westminster, I550-1800', in V. Fildes (ed.), Women as Mothers in Pre-Industrial England (1990), I39-I78.

49 Harding, 'Families and Housing', I36.

${ }^{\circ}$ GLMS, 9234/8, f. 4 . See also Forbes, Chronicle from Aldgate, $\mathrm{I} 7-\mathrm{I} 9,3 \mathrm{I}-4$.

${ }^{51}$ GLMS, 9234/5, f. I28v.

52 Dabhoiwala, 'Pattern of Sexual Immorality', 86.

53 Ibid., 96, and Gowing, 'Freedom of the Streets', I33, I39. Gowing notes that a crisis in household order might be linked to an apparent female threat to male authority. Gowing, 'Freedom of the Streets', I35. 
${ }^{54}$ Men abandoning women were punished only if their families were likely to become a burden on the parish, and so it was likely that 'untold numbers of couples did cohabit "as man and wife" for extended periods, having children together and not being called to account for many years if at all'. It has been estimated that, by the later seventeenth century, most inhabitants were not married according to the conventions of the church, but in clandestine or otherwise private and irregular ceremonies. See Dabhiowala, 'Pattern of Sexual Immorality', 92. This may have been true of Aldgate in particular, given that it was flanked by two of London's principal centres for clandestine marriage $-\mathrm{St}$ James Dukes Place and Holy Trinity Minories. See Tomlinson, History of the Minories, 226; and J. Boulton, 'The Marriage Duty Act and Parochial Registration in London, I695-I706', in Schurer and Arkell, Surveying the People, 222-52, on 232-3. Clandestine marriage, among other things, was seen as a means of tax evasion. See Arkell, 'Examination of the Poll Taxes', I70; and Boulton, 'Marriage Duty Act', 228-3I.

${ }^{55}$ Forbes, Chronicle from Aldgate, 37-8; see also Forbes, Chronicle from Aldgate, I7, 29-30, 32.

${ }^{56} 6 \& 7 \mathrm{Wm}$ and M., c. 6; Statutes of the Realm, VI, 583 .

${ }^{57} \mathrm{LMA}, \mathrm{COL} / \mathrm{CHD} / \mathrm{LA} / 04 / 01 / 004,053,062,063$, IO2.

${ }^{58}$ Harding, 'Families and Housing', I36-7.

59 Schurer has suggested that, in London, the wealthier the parish (defined by the number of households liable for a surtax in the marriage duty assessments), the more likely there was to be extended kin in the family. He found that 'households headed by a married couple were less likely to record a high percentage of households with [extended] kin. This seems to suggest that the absence of a spouse encouraged the presence of a relative, either as a spouse-substitute, maybe to help pay household expenses, or perhaps due to the greater availability of accommodation'. See Schurer, 'Variations in Household Structure', 269 (quotation), 275. Spence found that only 4.4 per cent of London households contained co-resident 'extended' kin. See Spence, London in the I690s, 94-5.

${ }^{60}$ The most common category of co-resident extended kin is that of a householder's sister. There are also examples of mothers, fathers, aunts, sons-in-laws, and cousins.

${ }^{61}$ Wall, 'Regional and Temporal Variations', IO2, I06; Earle, City Full of People, I60; 'Gregory King on the State of England in I695', in J. Thirsk and J. P. Cooper (eds), Seventeenth-Century Economic Documents (Oxford, I97I), 776-8.

${ }^{62}$ Schurer, 'Variations in Household Structure', $27 \mathrm{I}$.

${ }^{63}$ For example, many childless households are listed in the poll tax returns because the children of day labourers were exempted from the tax. See Alexander, 'City Revealed', ı86.

${ }^{64}$ Boulton has suggested that under-registration of births was a worse problem in small, rich innercity parishes than in the larger, poor extramural parishes. See Boulton, 'Marriage Duty Act', 237-9. Schurer suspected that the average age of the inhabitants of the richer central parishes was higher than in the poorer suburbs, so that children were more likely to have grown up and left. See Schurer, 'Variations in Household Structure', 275. Spence, on the other hand, has mapped the opposite pattern, suggesting that inner-city households contained larger numbers of children than suburban districts. See Spence, London in the I690s, 91.

${ }^{65}$ G. Newton, 'Infant Feeding Practices, Social Status and Mortality Variation in London, C.I550-I750', Social History of Medicine, forthcoming.

${ }^{66}$ Spence found that 19.2 per cent of London children listed in the I690s poll tax returns had a single resident parent. See Spence, London in the I69os, 94 .

${ }^{67}$ For example, see Forbes, Chronicle from Aldgate, $32-3,37-8,67-9,76$, I50, 193-5.

${ }^{68}$ A. G. B. Atkinson, St Botolph Aldgate (I898), I29-30.

${ }^{69} \mathrm{LMA}, \mathrm{COL} / \mathrm{CHD} / \mathrm{LA} / 04 / 01 / 004,053,062,063$, IO2.

${ }^{70} \mathrm{LMA}, \mathrm{COL} / \mathrm{CHD} / \mathrm{LA} / 04 / 01 / 004,053,062,063$, IO2.

${ }^{71}$ See the comments above on p. 2 I7.

${ }^{72} \mathrm{LMA}, \mathrm{COL} / \mathrm{CHD} / \mathrm{LA} / \mathrm{O} / \mathrm{oI} / \mathrm{IO} 2$; LMA, COL/CHD/ LA/04/or/o62. Forty-two of St Mary le Bow's I8 5 households contained one or more apprentices; 43.8 per cent (46) of the parish's houses accommodated at least one apprentice. In Tower Hill, I5.6 per cent of houses (35) accommodated one or more apprentices.

${ }^{73} \mathrm{LMA}, \mathrm{COL} / \mathrm{CHD} / \mathrm{LA} / 04 / 01 / 004,053,062,063$, IO2. Twenty-three of the 69 apprentices listed in St Mary le Bow were assessed at higher than basic rate; in Tower Hill, only one of the 58 listed apprentices is so rated (I.7 per cent). See LMA, COL/CHD/ LA/O4/OI/O62; and LMA, COL/CHD/LA/O4/OI/IO2.

${ }^{74}$ Alexander believes that the assessments provide the most accurate picture of individual wealth in seventeenth-century London. See Alexander, 'City Revealed', I9I-2.

${ }^{75} \mathrm{LMA}, \mathrm{COL} / \mathrm{CHD} / \mathrm{LA} / 04 / 01 / 004,053,062,063$, IO2.

${ }^{76}$ Harding, 'Families and Housing', I30.

77 This accords with Spence's findings on the relative wealth of the two areas in his analysis of the $4 \mathrm{~s}$. aids, where a distinct correlation was found between high rent values and the concentration of wealthy lodgers. See Spence, London in the I69os, 98-9. 


\section{Acknowledgements}

We are grateful to conference and seminar audiences in London and Cincinnati, and especially to Derek Keene and Vanessa Harding for their comments on earlier versions of this paper.

\section{Notes on Contributors}

Mark Merry is Senior Research Officer on the ESRC-funded project 'Life in the suburbs: health, domesticity and status in early modern London' at the Centre for Metropolitan History, IHR. His research focuses on the social aspects of urban living in the period I450-I700, to which he brings record linkage and mapping techniques in order to elucidate patterns and networks.

Philip Baker is Senior Research Officer at the Centre for Metropolitan History, Institute of Historical Research, London. His research interests include the social and economic history of early modern London, and the political and religious history of mid-seventeenth-century London and England more generally. 